DOI: $10.30519 /$ ahtr.525116

Advances in Hospitality and Tourism Research (AHTR)

\title{
THE EFFECTS OF P-O ETHICAL FIT, EXPECTED PAY AND CORPORATE IMAGE ON JOB CHOICE DECISION ${ }^{1}$
}

\author{
Zhu-ying WANG \\ Department of Business Administration, Providence University, Taichung, Taiwan \\ ORCID: 0000-0002-1059-3079 \\ Wen-ching CHANG ${ }^{2}$ \\ Department of Business Administration, Providence University, Taichung, Taiwan \\ ORCID: 0000-0003-2709-1451
}

\begin{abstract}
Our research extends the current recruiting relevant studies by identifying how intrinsic (person-organization ethical fit, P-O ethical fit) and extrinsic factors (pay level and perceived corporate image) influence job choice decision solely and interactively. A $2 \times 2$ between-subjects experimental design was conducted with 210 graduating students in Taiwan, and written scenarios were used to simulate a job choice setting. These scenario cases are related to hotels which focus on environmentally relative corporate social responsibility (CSR) activities. The results show a significant difference in job offer acceptance rates among job seekers with diverse $\mathrm{P}-\mathrm{O}$ ethical fit and the effect of $\mathrm{P}-\mathrm{O}$ ethical fit on perceived corporate image was partially supported. The following discussion and suggestion will be made to provide ideas for recruiting management and it will also contribute to academic research.
\end{abstract}

\section{Article History}

Received 1 October 2018

Revised 10 February 2019

Accepted 14 February 2019

\section{Keywords}

ethical fit job choice decision corporate image pay

\footnotetext{
1 An earlier version of this study was presented at the 8th Advances in Hospitality and Tourism Marketing and Management (AHTMM) conference, Bangkok, Thailand, June 2018.

${ }^{2}$ Address correspondence to Wen-ching Chang, Department of Business Administration, Providence University, Taiepei, TAIWAN. E-mail: wcchang2@pu.edu.tw
} 


\section{INTRODUCTION}

Applicant job decisions are motivated not only by extrinsic motivation but also by intrinsic motivation (Deci \& Ryan, 2000; Gagné \& Deci, 2005). McGinley et al.'s (2018) study highlighted the power of an organization's status on its attractiveness to job seekers. Moreover, it indicated a significant positive interaction effect with individuals' need for status. According to motivation theories, extrinsic motivation is derived from linkages between job choice decision and external rewards such as monetary factors, whereas intrinsic motivation comes from job seekers' perception of an organization or personal interests in a job. The results of one meta-analytic study by Chapman et al. (2005) also stated that nonmonetary attributes such as job, organization, and recruiter attributes were all related to applicant acceptance intention and job choice decision. Thus, identifying the effects of intrinsic versus extrinsic motives to recruitment has become an important issue for employers.

Surroca et al.'s (2010) study highlighted the significance of recruiting and hiring employees with attitudes and values that fit the corresponding organization. The attraction-selection-attrition (ASA) model supports the ideas that job seekers will be more attracted to organizations whose values match their own (Schneider, 1987; Smith, 2008), and research on person-organization fit (P-O fit) demonstrate that employees are attracted and committed to organizations that better fit their values (Judge \& Cable, 1997; Kristof, 1996; Lievens et al., 2001; Schneider, 1987; Smith, 2008). In line with this logic, Finegan \& Theriault (1997) evaluated the relationship between corporate codes of ethics and P$\mathrm{O}$ fit, determining that the more an employee's personal values are reflected in a company's code of ethics, the more favorably the employee will evaluate the value of the code of ethics. These findings can be viewed as the better P-O ethical fit between job seekers and corresponding organization, the higher applicants' intent to apply for or accept the job offer will be. However, there is no evidence indicating how different conditions of the match will affect applicants' job search decision. The current experimental research thus attempted to test the effects of four different $\mathrm{P}-\mathrm{O}$ ethical fits on applicants' job decision choice.

Pay level, one kind of extrinsic motivators, has been known as an essential factor influencing applicants' job choice decisions (Cable \& Judge, 1994; Chapman et al., 2005; Jurgensen, 1978; Rynes \& Cable, 2003). Job seekers look for a job that will allow them to make a decent material living (Cable \& Judge, 1994) and prefer higher-paying jobs to lower- 
paying jobs (Rynes \& Cable, 2003). For this reason, employers who provide more monetary incentives than other prospective employers are more likely to effectively attract targeted applicants. Therefore, we used the expected pay as one of the predictors in this study to identify its effect on applicants' job seeking decision.

A study by Gatewood et al. (1993) pointed out that job seekers have a higher willingness to apply for companies with a better reputation, in other words, job seekers' perceptions of the company when choosing a job opportunity are also an important factor in their consideration (Collins \& Stevens, 2002). Along with logic, the current research also tests the effect of organization image on applicants' job choice decision, and furthermore to investigate what is the linkage between different $\mathrm{P}-\mathrm{O}$ ethical fits and job seekers' perceived corporate image and how it relates to their job choice.

The effects of individual characteristics interact with organizational attributes to affect perceived fit, attractiveness, and job choice has been investigated on the previous recruitment research (e.g. Cable \& Judge, 1996; Erdogan \& Bauer, 2005; Judge \& Cable, 1997). Other work has focused on how the intrinsic and extrinsic motivators influence job seekers' attitudes, intentions, and perceived fit, and choices (Allen et al., 2007; Deci \& Ryan, 2000; Gagné \& Deci, 2005). Our research extends the current recruiting relevant studies by identifying how intrinsic ( $\mathrm{P}-\mathrm{O}$ ethical fit) and extrinsic factors (pay level and perceived corporate image) influence job choice decision solely and interactively.

\section{LITERATURE REVIEW}

Applicants looking for a job that enables them to make a decent material living is the reason that applicants seek a job (Cable \& Judge, 1994) and prefer higher-paying jobs to lower-paying jobs (Rynes \& Cable, 2003). The wider the range of pay level within the applicants' job pool, the greater the salient effect the pay level has on job choice (Highhouse et al., 1999). Pay level, therefore, has been acknowledged as an important factor influencing applicants' job choices (Cable \&Judge, 1994; Chapman et al., 2005; Jurgensen, 1978; Rynes \& Cable, 2003). For this reason, employers who provide more monetary incentives than other prospective employers are more likely to successfully attract targeted applicants. We thus propose the following hypothesis:

H1: Expected pay will positively relate to job seekers' job choice decision. 
In the past few decades, researchers have continued to study the factors of which organizations attract job seekers, especially those related to job searching decisions (Barber, 1998). Personal-Organization fit (P-O fit) has been extensively studied in organizational behavior and business fields (e.g. Ambrose et al., 2008; Cable \& Judge, 1996; Firfiray \& Mayo, 2017; Gully et al., 2013; Valentine et al., 2002). Cable and Judge (1996) explain the idea of $\mathrm{P}-\mathrm{O}$ fit from the job seekers' perspective in that job seekers prefer organizations that have the same personality as they do. Judge and Cable (1997) continue to indicate that job seekers often attempt to match their values with an organization's reputation. Much research also proves the strong and important effects of the positive relationship between employees and the organizations on employee recruitment and retention, and job seekers often try to match their values to the organization's reputation (see Cable \& Judge, 1996; Chatman, 1991; Ehrhart \& Ziegert, 2005; Judge \& Cable, 1997). These findings support that ethical fit is an important feature of personal organizational fit and affects employees' willingness to apply for jobs (Sims \& Kroeck, 1994). Although corporate social responsibility (CSR) does not totally represent ethics, it is an ethical behavior metric that reflects organizational culture and values and is easily understood by people. Therefore, we use CSR practice as the signal of the ethical value of an organization.

Several theoretical models demonstrate the importance of organizational characteristics to applicants' job-searching outcomes. For example, Signal Theory (Spence, 1973) shows how prospective job seekers may utilize clues provided by the organization and use them to support the job choice decision process (Wanous, 1992). The linkage between CSR and financial performance is noted by Branco and Rodrigues (2006). They demonstrate that companies known by its good social responsibility reputation may attract better employees or motivate and increase current employees' motivation and morale as well as their commitment and loyalty to the company, thereby improving financial outcomes. Turban and Greening (1997) argued that a firm's CSR practices can be seen as an important attracting factor of potential employees. For job seekers, job search decisions will also be based on subjective perceptions and judgments of the company's "organizational image" and will be a key factor influencing job seekers' perceived strengths and weaknesses (Barber, 1998). Along with this logic, the current research employs four types of P-O ethical fit which are positive hotel CSR and high cognition of CSR (PH), positive hotel CSR and low cognition of CSR (PL), negative hotel CSR and high cognition of CSR (NH), and negative hotel CSR and 
low cognition of CSR (NL) to test the effects of P-O ethical fit on job seekers' job choice decision. We propose the following hypotheses:

H2: There is a significant difference among P-O ethical fit on job seekers' job choice decision. PH fit will make job seekers more likely to accept job offer than the other 3 kinds of fits.

Corporate image is an abstract concept that is the subjective attitude and feeling of the customer's perception or message about a particular product or service type given by the organization (Boulding, 1956). This perspective is similar to Riordan et al. (1997), which states that corporate image is the basis of corporate identity and determines the stakeholder's perception of corporate-related activities. Scholars conducted research on organizational brands and recruiting indicating a positive correlation between the image of the top 500 companies and college students' job-seeking tendencies (Gatewood et al., 1993). Therefore, internal and external image management has a significant influence on the brand (Duncan \& Moriarty, 1998), it not only positively related to consumers' (Liat et al., 2014) and employees' perceptional and behavioral outcomes but also the specific presentation of the company's brand (Hoeffler \& Keller, 2002). Rynes et al. (1991) also had a result in a research regarding to job attractiveness that organizational social performance and culture affect new employees' willingness to apply. Organizations with better social performances can also attract better job seekers and have better recruitment results. Zairi and Peters (2002) pointed out that when companies fulfill their social responsibilities, they will have a positive impact on the corporate image and help maintaining the relevant competitive advantage of the company. It can be seen that CSR is not just a pursuit of international trends, but one of the means to improve the corporate image and enhance competitive advantage. Therefore, following hypotheses were proposed:

H3: Job seekers with different P-O ethical fit will have a significant difference in the perceived corporate image. Job seekers with $\mathrm{PH}$ fit will have a higher level of the perceived corporate image than the other 3 kinds of fits.

H4: The interaction among P-O ethical fit, perceived corporate image, and expected pay will affect job seekers' job choice decision. 


\section{METHODOLOGY}

The study was carried out with a $2 \times 2$ experimental design (see Table 1 ). Two well-known hotels that actually exist in the Sun Moon Lake Soil and Water Conservation Area, where is located in central Taiwan, were selected and their information was rewritten to establish the basic information content and the social responsibility practices of the two scenario hotels. This study used a single set of pre- and post-test design. All subjects were randomly assigned to two CSR settings. Participants were categorized to the high or low cognition of CSR team by their scores of CSR cognition scales. The cutoff point was the mean $(m=5.94)$ of individuals' cognition of CSR. In the end, every participant was classified to one of the following ethical P-O groups:

1. PH- positive Hotel CSR and high cognition of CSR

2. PL- positive Hotel CSR and low cognition of CSR

3. NH- negative Hotel CSR and high cognition of CSR

4. NL-negative Hotel CSR and low cognition of CSR.

Table 1. The P-O ethical fit between job seekers and hotel

\begin{tabular}{|l|c|c|c|}
\multicolumn{2}{|l|}{} & \multicolumn{2}{|l|}{ Job seekers' cognition of CSR (n=210) } \\
\cline { 2 - 4 } & Positive( CSRP) & High & Low \\
\hline \multirow{3}{*}{ Hotel CSR } & & & PL $(\mathrm{n}=59)$ \\
\cline { 2 - 4 } & Negative (CSRN) & $\mathrm{NH}(\mathrm{n}=51)$ & $\mathrm{NL}(\mathrm{n}=54)$ \\
& & & \\
\hline
\end{tabular}

\section{Procedure}

A brief introduction of this research project was given by the researcher in person and the materials were distributed to all participants in several undergraduate classes in Management College located in central Taiwan. All participants were graduate students or senior students of undergraduate programs who are going to graduate within 6 months, so 
that they were qualified potential job applicants. There are 3 steps in this experiment:

Step 1: All participants were asked to complete the CSR cognition survey.

Step 2: All participants read the same scenario about the introduction to the Hotel and its recruitment advertisement. The information of the average salary in this industry was offered, and then participants were asked to provide their expected pay if they were to apply for this job.

Step 3: Two different environmental protection relevant CSR scenarios were assigned in this step. Two scenario articles were rewritten from real reported cases derived from public media in the Sun Moon Lake soil and water conservation area in Taiwan. We used these two scenarios to describe the positive CSR and negative CSR settings. All participants answered their perceived corporate image of the hotel and their willingness to accept a job offer provided by the hotel after reading these descriptions.

(1) Hotel with positive CSR (CSRP): News report related to positive CSR.

(2) Hotel with negative CSR (CSRN): News report related to negative CSR.

\section{Participants}

College graduates were used as samples in many previous studies (e.g. Carless, 2005; Kim \& Park, 2011; Quinetta et al., 2005), because these students were very close to joining the job market. They were seen as potential job seekers in the very near future. This research, therefore, used these senior students who are going to join the market within 6 months as experimental subjects. Experiment was conducted in February and March 2018. The participants include 200 senior undergraduate business students at a university in central Taiwan. Across the sample, the distribution of the age groups was $82.4 \%$ under 22 years old (minimum age was 18), 15.2\% was 23 years old, $1.0 \%$ was 24 years old, and $1.4 \%$ was older than 25 years old. Men comprised $29 \%$ of the sample. All data used in this study were collected from written surveys distributed and collected in respondents' classrooms by the first author at the university during a regularly scheduled class period. Each participant received a package containing instructions, surveys, and scenario case. Respondents were asked to read the scenarios while imagining themselves as job seekers preparing to apply for a job in the case hotel. All participants were randomly assigned 
to 2 case hotel settings, and participants were grouped to high or low CSR cognitive awareness based on the results of their answers to the CSR cognition scale.

\section{Measurement Scales}

CSR Cognition Scale. This scale was adopted from Park (2009). A total of 27 items were incorporated into the six dimensions of this scale, and 2 unrelated dimensions were excluded in this study. All items were rated on a 7 -point Likert scale $(1=$ strongly disagree, $7=$ strongly agree). Example items of each dimension were: The hotel implements renewable energy programs; the hotel implements recycling programs; the hotel implements a linen and towel reuse program; the hotel purchases locally produced ingredients; the hotel implements environmental training programs; and, the hotel supports local communities to enhance the local environment. The overall fit supports the measurement model and the $\chi^{\wedge} 2$ fit statistic is 291.3 with 146 degrees of freedom $(p<.001)$. The RMSEA is .069 and the CFI is .98. The measures demonstrate adequate construct validity and reliability.

Perceived Corporate Image. The 4-item scale was adopted by De Wulf et al. (2001). These four items were "I think the social image of this hotel is very good", "This hotel has a good reputation", "I think this hotel will have a higher social rating", and "I think this hotel can be trusted". The Cronbach's alpha was .97 for the scale.

Expected Pay. This variable was measured with one item: "What is your expected salary for this job?" Participants were asked to put a check mark on the box representing the expected pay for his or her job.

Job Choice Decision. One dichotomous item was used to measure this variable: "Would you accept this job offer or not?" Participants were asked to put a check mark on the box of Yes or No. In this study, we were particularly interested in knowing whether participants would accept the job offer when considering intrinsic and extrinsic factors.

\section{RESULTS}

In consideration of the effects of confounding variables, results from a series of chi-square tests and analyses of variance (ANOVA) indicate that 
participants' gender $((\chi(1)=1.17, \mathrm{p}=0.28)$ and age $(\mathrm{F}=0.48, \mathrm{p}=0.77)$ did not significantly differ across the four experimental conditions. Table 2 lists the means, standard deviations, and inter-correlations among all study variables.

Table 2. Descriptive Statistics and Correlation of the Variable $(N=210)$

\begin{tabular}{|c|c|c|c|c|c|c|c|c|}
\hline Variable & $\mathrm{m}(\mathrm{sd})$ & PH & PL & NH & NL & CI & JCD & EP \\
\hline 1. Ethical P-O fit-PH ${ }^{a}$ & - & 1 & & & & & & \\
\hline 2. Ethical $\mathrm{P}-\mathrm{O}$ fit-PL ${ }^{b}$ & - & $.331^{-}$ & 1 & & & & & \\
\hline 3. Ethical P-O fit-NH $\mathrm{NH}^{\mathrm{c}}$ & - & $.368^{* *}$ & $.312^{-}$ & 1 & & & & \\
\hline 4. Ethical P-O fit- $\mathrm{NL}^{\mathrm{d}}$ & - & $.354^{-}$ & $.300^{-}$ & $.333^{*}$ & 1 & & & \\
\hline $\begin{array}{l}\text { 5. Perceived Corporate } \\
\text { Image (CI) }\end{array}$ & $4.52(1.62)$ & $.554^{* *}$ & $.274^{* *}$ & $\begin{array}{r}- \\
.482^{* *}\end{array}$ & $\begin{array}{r}- \\
.353^{* *}\end{array}$ & 1 & & \\
\hline $\begin{array}{l}\text { 6. Job Choice } \\
\text { Decision(JCD)e }\end{array}$ & - & $.343^{* *}$ & 128 & $.328^{* *}$ & $.149^{*}$ & $.517^{* *}$ & 1 & \\
\hline 7. Expected Pay (EP) & .42(.50) & .079 & -.032 & -.026 & -.025 & .045 & 019 & 1 \\
\hline
\end{tabular}

Table 3. P-O Ethical Fit * Job Choice Decision Cross-Tabulation

\begin{tabular}{cccc}
\hline \multirow{2}{*}{ P-O Ethical Fit } & & \multicolumn{2}{c}{ Job Choice Decision } \\
No & Yes \\
\hline \multirow{2}{*}{$\mathrm{PH}$} & $\mathrm{n}$ & 18 & 41 \\
& $\%$ of all & $8.6 \%$ & $19.5 \%$ \\
\hline \multirow{2}{*}{$\mathrm{PL}$} & $\mathrm{n}$ & 21 & 25 \\
& $\%$ of all & $10 \%$ & $11.9 \%$ \\
\hline \multirow{2}{*}{$\mathrm{NH}$} & $\mathrm{n}$ & 46 & 8 \\
& $\%$ of all & $21.9 \%$ & $3.8 \%$ \\
\hline \multirow{2}{*}{$\mathrm{NL}$} & $\mathrm{n}$ & 36 & 15 \\
& $\%$ of all & $17.1 \%$ & $7.1 \%$ \\
\hline
\end{tabular}

Note: $\chi^{2}(3, N=210)=40.77, p=.00$

Table 3 reports the results of the difference of job seekers with diverse kind of $\mathrm{P}-\mathrm{O}$ ethical fit on their job choice decision. Chi-square test is most commonly used for the testing of relationships between categorical variables, especially when the number of samples is too small, for 
example, the number of samples per group is less than 30 (Gay, 1992). In support of Hypothesis 2, the chi-square result revealed a significant difference $\left(\chi^{2}(3, \mathrm{n}=210)=40.77, \mathrm{p}=0.00\right)$. The percentage of agreeing to accept the job offer in the group of job seekers with $\mathrm{PH} \mathrm{P}-\mathrm{O}$ ethical fit $(19.5 \%)$ is higher than the rest of the three groups (PL, $11.9 \%$; $\mathrm{NH}, 3.8 \%$; NL, $7.1 \%$ ).

One-way ANOVA was used to test the effect of P-O ethical fit on the perceived corporate image, the results shown in Table 4. Results indicating significant differences in diverse $\mathrm{P}-\mathrm{O}$ ethical fit on the perceived corporate image $\left(\mathrm{F}(3,206)=82.68, \mathrm{p}=0.000, \eta_{p}^{2}=.5 .5\right)$. The post-hoc analysis revealed that (1) group with $\mathrm{PH}(\mathrm{m}=5.95, \mathrm{sd}=.78)$ is significantly $(\mathrm{p}=0.00)$ higher than group with $\mathrm{NH}(\mathrm{m}=3.20$, $\mathrm{sd}=1.32)$; (2) group with $\mathrm{PH}$ is significantly $(p=0.00)$ higher than group with $\mathrm{NL}(\mathrm{m}=3.52, \mathrm{sd}=1.33)$; (3) group with PL $(m=5.36$, $s d=.85)$ is significantly $(p=0.00)$ higher than group with $\mathrm{NH}$; and (4) group with PL is significant higher than group with $\mathrm{NH}$ $(p=.00)$, but there are no significant differences between group $\mathrm{PH}$ and group PL, and group NH and group NL. These results partially support Hypothesis 3.

Table 4. ANOVA Result of the P-O Ethical Fit on Perceived Corporate Image $(n=210)$

\begin{tabular}{ccccccc}
\hline Source of & SS & df & MS & F & P & $\eta_{p}^{2}$ \\
Variability & & & & & & 0.000 \\
Fit & 299.34 & 3 & 99.78 & 82.68 & 0.55 \\
Error & 248.62 & 206 & 1.21 & & & \\
Total & 547.96 & 209 & & & & \\
\hline
\end{tabular}

As shown in Table 5, the effect of expected pay on job choice decision shown in model 1 indicated no significant result $(\beta=-0.04, p>$ 0.05). Therefore, Hypothesis 1 was not supported. Nevertheless, the P-O ethical fit, perceived corporate image, and expected pay did not have significant interaction effects on job choice decision $(\beta=-0.66,-0.50,-0.23$, $0.02, \mathrm{p}>0.05$; see Table 5). These outcomes were inconsistent with Hypothesis 4 . 
Table 5. Results of Logistic Regression with Dependent Variable as Job Choice Decision

\begin{tabular}{|c|c|c|c|}
\hline \multirow[b]{2}{*}{ Variables } & \multicolumn{3}{|c|}{ Job Choice Decision } \\
\hline & Model 1 & Model 2 & Model 3 \\
\hline \multicolumn{4}{|l|}{ Intrinsic Variable } \\
\hline Ethical fit- $\mathrm{PH}[\mathrm{H} 1]$ & $4.23^{* *}$ & $3.24^{*}$ & 2.19 \\
\hline Ethical fit- PL [H1] & $3.98^{* *}$ & 1.67 & 1.94 \\
\hline Ethical fit- NL[H1] & $3.40^{*}$ & 4.00 & 5.65 \\
\hline Ethical fit- NH [H1] & $4.19^{* *}$ & 2.86 & 4.12 \\
\hline Perceived Corporate Image (CI) & $.78^{* *}$ & $.55^{*}$ & .50 \\
\hline \multicolumn{4}{|l|}{ Extrinsic Variable } \\
\hline Expected pay (EP) [H2] & -.04 & .05 & .06 \\
\hline \multicolumn{4}{|l|}{ Two-way interaction terms [H4] } \\
\hline $\mathrm{PH} \times \mathrm{CI}$ & & .46 & 2.16 \\
\hline PLXCI & & .51 & 1.71 \\
\hline LH×CI & & .28 & .80 \\
\hline $\mathrm{NH} \times \mathrm{CI}$ & & - & - \\
\hline PHХEP & & -.20 & .76 \\
\hline PLXEP & & .42 & .84 \\
\hline NLXEP & & -.82 & -.99 \\
\hline NHXEP & & - & - \\
\hline \multicolumn{4}{|l|}{ Three-way interaction terms } \\
\hline PHXCIXEP & & & -.66 \\
\hline PLXCIXEP & & & -.50 \\
\hline NLXCIXEP & & & -.23 \\
\hline NHXCIXEP & & & .02 \\
\hline -2 Log likelihood & 218.68 & 213.246 & 208.64 \\
\hline Cox \& Snell $R^{2}$ & .292 & .31 & .33 \\
\hline NagelkerkeR² & .389 & .41 & .43 \\
\hline
\end{tabular}

Note: $* * p<.001, * p<.01$

\section{DISCUSSION}

The present study investigates the intrinsic and extrinsic motivators, namely P-O ethical fit, the perceived corporate image, and expected pay of job seekers on their job choice decision. Previous research in job choice contexts revealed that applicant decision making is both determined by extrinsic and intrinsic motivation, and job seekers are motivated to choose a job which provides external rewards or possesses consistent values with them. In the current study, the hypothesis testing the effect of pay on job choice decision was not supported. Pay level, one of the monetary factors, can induce applicants' external motivation, while non-monetary attributes 
such as P-O fit may affect their intrinsic motivation to accept the job. Applicants may choose a lower pay job with favorable non-monetary attributes as they are motivated by intrinsic motivation rather than extrinsic motivation. Our result implied that there may be determinants of job seekers' decisions other than expected pay, in turn raising the possibility that other attributes, especially non-monetary attributes, may have stronger effects on job seekers' acceptance of a job offer.

Research has uncovered evidence that job seekers consider nonmonetary attributes during the recruitment process (Cable \& Judge, 1994; Chapman et al., 2005; Jurgensen, 1978; Rynes \& Cable, 2003). Previous research indicated that there is a positive effect of $\mathrm{P}-\mathrm{O}$ fit and organizational attractiveness towards job choice. This research took it one step further by investigating the effect of ethical value match between organization and individual. We categorized it into 4 types and tested the relationships between them and job choice decision. Comparing positive and negative fits, we found that job seekers are more likely to accept a job offer when they have positive P-O ethical fit with the counterpart hotel; whereas job seekers are less likely to accept a job offer with the negative P$\mathrm{O}$ ethical fit. The positive fit also facilitates job seekers to have a higher degree of the perceived corporate image than others. In two dis-match conditions, it was found that job seekers who have higher CSR cognition exhibit the lowest job acceptance rates with hotels with negative CSR. These findings primarily confirmed Cable and Judge's (1996) statement that "Job seekers prefer organizations that have the same "personality" as they $\mathrm{do}^{\prime \prime}$, but further clarified that only positive fit may have a meaningful influence on applicants' job choice decision when considering ethical value fit. We also found that job seekers with positive $\mathrm{P}-\mathrm{O}$ ethical fit have a significantly higher level of the perceived corporate image than applicants' in groups NL and PL. Our statistical results also indicated that job seekers with high CSR cognition will have a higher perceived corporate image than those with low CSR cognition after reading positive CSR reports of the scenario Hotel. After reading negative CSR reports of the scenario Hotel, applicants with high CSR cognition have lower perceived corporate image of this Hotel than those with lower CSR cognition. These findings aligned with Branco and Rodrigues (2006), Fombrun and Shanley (1990), and Turban and Greening's (1997) studies that conducting CSR creates and delivers a positive corporate image of an organization to the public which increases positive feelings of the public to the organization and continues to improve organizational attractiveness. 
This effect will be more significant while there is a positive match between personal and organizational ethical value.

Such results can be verified through a person-organization fit; basically, the organization preferred by the job seeker is the organization's attributes that work closely with its personality traits (Chatman, 1989; Chatman, 1991; Judge \& Bretz, 1992; Cable \& Judge, 1994). Organizational credibility and image play an important role in the appeal of job seekers (Cable \& Turban, 2001; Tom, 1971). As Soelbe (1967) suggests that initial screening judgment is an important part. Job seeker's initial preference is usually determined by limited information. The rest of the decisionmaking process is mostly about confirmation. In other words, the job seeker will judge the preference of the company according to the information provided by the company in the early stage of the job search. Therefore, if the information provided by the company is preferred by the job seeker, it means that the two parties are more consistent in image or attribute. And, in turn, this may increase the willingness to seek employment, so the results of this study are similar to those of past studies. Therefore, in this study, if the value congruence between the individual and the organization is positive and higher, it means that they are more suitable for each other.

\section{CONCLUSION}

The effects of ethical fit between the organization and individual and perceived organizational image are more powerful than the pay level at attracting applicants. And the explanation for this preference is that most applicants want to work for a company which shares similar values with them rather than driven merely by external inducements. In addition, this effect of value match on accepting a job offer is stronger for applicants who have a positive ethical fit with their counterpart organization. From these findings, employers should be able to identify their core ethical value, form their organizational culture and engage in relevant CSR. Furthermore, to communicate their ethical value and CSR performance with their potential job seekers at an early stage, thus enabling them to convey information about non-monetary attributes suited to job seekers. 


\section{Practical Implications}

The degree of suitability of the individual's own image and the organizational image has a positive impact on the attractiveness of the organization; the higher the suitability of each other, the stronger the attraction of the organization. Basically, the organization of job seekers' preference is that the attributes of the organization are closely related to their personality traits. Netemeyer et al. (1997) argue that the general meaning of individual-organizational adaptation refers to the consistency between individual personality traits, beliefs, goals, and values, and organizational culture, strategic needs, organizational norms, organizational goals, and organizational values. If the similarity between the individual and the organization is higher, it means that they are more suitable for each other.

In this study, it was found that when participants read the news about the social responsibility of the case hotel, the perception of its image has a multiplier effect. In other words, to conceal the organization's wickedness and boast of its goodness has a great significance to the establishment and maintenance of its corporate image. This study provided the CSR relevant report in the newspaper of the case hotel to participants as media for communicating with the applicants about the hotel's CSR. The company itself should consider what kind of media should be used to communicate its concept of corporate philosophy, corporate culture, and values to actual performance. All these should be consistent. It is because, in the early stages of job hunting, job seekers mostly judged their company based on limited information. If companies can give potential candidates a message that fully reflects their important core values at this stage, then they can attract candidates with the same values.

\section{Limitation and Future Research Directions}

There are some limitations to this research. First, generalizability concerns may be raised by using student samples as potential applicants. However, participants in the study were undergraduates on the verge of receiving their degree. They were intending to search for a job within one year. Additionally, past research that used graduating students as potential applicants suggested that the job-seeking decision processes of graduating students are similar to those of real applicants (Turban et al., 1995). Future 
studies are nevertheless needed to apply our findings to test other types of job seekers (Breaugh \& Starke, 2000).

Second, we provided a reference level for industrial wages in the hospitality industry. This reference may result in the anchoring effect of the participants on the expected pay. In addition, the effect of pay level on job acceptance intention and choice varies for applicants at different stages of job seeking (Harold \& Ployhart, 2008). The current study focused solely on the final job choice decision. Research suggested that applicants' jobchoice strategies may vary from one recruitment-process stage to another (Osborn, 1990). Moreover, the job-choice factors that applicants take into consideration vary from one recruitment stage to the next (Uggerslev et al., 2012). Future research is suggested to use a sequential manipulation to explore the changes in the expected pay of the applicant at the different stages during the job-seeking processes and explore how applicants combine monetary and non-monetary attributes in these stages.

\section{REFERENCES}

Allen. D. G., Mahto, R.V., \& Otondo, R. F. (2007). Web-based recruitment: Effects of information, organizational brand, and attitudes toward a Web site on applicant attraction. Journal of Applied Psychology, 92, 1696-1708.

Ambrose, M., Arnaud, A., \& Schminke, M. (2008). Individual moral development and ethical climate: The influence of person-organization fit on job attitudes. Journal of Business Ethics, 77(3), 323-333.

Barber, A. (1998). Recruiting Employees: Individual and Organizational Perspectives. Thousand Oaks, CA: Sage Publications.

Boulding, K. E. (1956). The Image: Knowledge in Life and Social. Ann Arbor, MI: University of Michigan Press.

Branco, M. C., \& Rodrigues, L. L. (2006). Corporate social responsibility and resourcebased perspectives. Journal of Business Ethics, 69, 111-132.

Breaugh, J. A., \& Starke, M. (2000). Research on employee recruitment: So many studies, so many remaining questions. Journal of Management, 26, 405-434.

Cable, D. M., \& Judge, T. A. (1994). Pay preferences and job search decisions: A personorganization fit perspective. Personnel Psychology, 47(2), 317-348.

Cable, D. M., \& Judge, T. A. (1996). Person-organization fit, job choice decisions, and organizational entry. Organizational Behavior and Human Decision Processes, 67(3), 294311.

Cable, D. M., \& Turban, D. (2001). Recruitment image equity: Establishing the dimensions, sources, and value of job seekers' organizational beliefs. Research in personnel and human resources management, 20, 115-163.

Carless, S. A. (2005). Person-job fit versus person-organization fit as predictors of organizational attraction and job acceptance intentions: A longitudinal study. Journal of Occupational and Organizational Psychology, 78, 411-429. 
Chapman, D. S., Uggerslev, K. L, Carroll, S. A., Piasentin, K. A., \& Jones, D. A. (2005). Applicant attraction to organizations and job choice: A meta-analytic review of the correlates of recruiting outcomes. Journal of Applied Psychology, 90, 928-944.

Chatman, J. A. (1989). Improving interactional organizational research: A model of person-organization fit. Academy of Management Review, 14(3), 333-349.

Chatman, J. A. (1991). Matching people and organizations: Selection and socialization in public accounting firms. Administrative Science Quarterly, 36(3), 459-484.

Collins, C. J., \& Stevens, C. K. (2002). The relationship between early recruitment-related activities and the application decisions of new labor-market entrants: A brand equity approach to recruitment. Journal of applied psychology, 87(6), 11-21.

De Wulf, K., Odekerken-Schröder, G., \& Iacobucci, D. (2001). Investments in consumer relationships: A cross-country and cross-industry exploration. Journal of Marketing, $65(4), 33-50$.

Deci, E. L., \& Ryan, R. M. (2000). The "what" and "why" of goal pursuits: Human needs and the self-determination of behavior. Psychological Inquiry, 11, 227-268.

Duncan, T., \& Moriarty, S. E. (1998). A communication-based marketing model for managing relationships. The Journal of Marketing, 62, 1-13.

Ehrhart, K. H., \& Ziegert, J. C. (2005). Why are individuals attracted to organizations? Journal of Management, 31(6), 901-919.

Erdogan, B., \& Bauer, T. N. (2005). Enhancing career benefits of employee proactive personality: The role of fit with jobs and organizations. Personnel Psychology, 58, 859891.

Finegan, J., \& Theriault, C. (1997). The relationship between personal values and the perception of the corporation's code of ethics. Journal of Applied Social Psychology, 27(8), 708-724.

Firfiray, S., \& Mayo, M. (2017). The lure of work-life benefits: Perceived personorganization fit as a mechanism explaining job seeker attraction to organizations. Human Resource Management, 56(4), 629-649.

Fombrun, C., \& Shanley, M. (1990). What's in a name? Reputation building and corporate strategy. Academy of Management Journal, 33(2), 233-258.

Gagné M., \& Deci, E. L. (2005). Self-determination theory and work motivation. Journal of Organizational Behavior, 26, 331-362.

Gatewood, R. D., Gowan, M. A., \& Lautenschlager, G.J. (1993). Corporate image, recruitment image and initial job choice decisions. Academy of Management Journal, $36(2), 414-427$.

Gay, L. R. (1992). Educational Research: Competencies for Analysis and Application (4th ed.). Merrill, NY: M. Macmillan International.

Gully, S. M., Phillips, J. M., Castellano, W. G., \& Han, K. (2013). A mediated moderation model of recruiting socially and environmentally responsible job applicants. Personnel Psychology, 66, 935-973.

Harold, C. M., \& Ployhart, R. E. (2008). What do applicants want? Examining changes in attribute judgments over time. Journal of Occupational and Organizational Psychology, 81, 191-218.

Highhouse, S., Stierwalt, S. L., Bachiochi, P. D., Elder, A. E., \& Fisher, G. (1999). Effects of advertised human resource management practices on attraction of African-American applicants. Personnel Psychology, 52, 425-442.

Hoeffler, S., \& Keller, K. L. (2002). Building brand equity through corporate societal marketing. Journal of Public Policy \& Marketing, 21(1), 78-89. 
Judge, T. A., \& Bretz, R. D. (1992). Effects of work values on job choice decisions. Journal of Applied Psychology, 77(3), 261-271.

Judge, T. A., \& Cable, D. M. (1997). Applicant personality, organizational culture and organization attraction. Personnel Psychology, 50, 359-394.

Jurgensen, C. E. (1978). Job preferences (What makes a job good or bad?). Journal of Applied Psychology, 63, 267-276.

Kim, S. Y., \& Park, H. (2011). Corporate Social Responsibility as an organizational attractiveness for prospective public relations practitioners. Journal of Business Ethics, 103, 639-653.

Kristof, A. L. (1996). Person-organization fit: An integrative review of its conceptualizations, measurement, and implications. Personnel Psychology, 49(1), 1-49.

Liat, C.B., Mansori, S., \& Huei, C.T. (2014). The associations between service quality, corporate image, customer satisfaction, and loyalty: Evidence from the Malaysian hotel industry. Journal of Hospitality Marketing \& Management, 23, 314-326.

Lievens, F., C., Decaeateker, C., \& Coetsier, P. (2001). Organizational attractiveness for prospective applicants: A person-organization fit perspective. Applied Psychology: An International Review, 50(1), 30-51.

McGinley, S. P., Yang, W., \& Zhang, L. (2018). Snob appeal? Impact of company status perceptions on employee recruitment. Journal of Hospitality Marketing \& Management, 27(1), 85-105.

Netemeyer, R.G., Boles, J.S., McKee, D.O., \& McMurrian, R. (1997). An investigation into the antecedents of organizational citizenship behaviors in a personal selling context. Journal of Marketing, 61(3), 85-98.

Osborn, D. P. (1990). A reexamination of the organizational choice process. Journal of Vocational Behavior, 36, 45-60.

Park, J. (2009). The relationship between top managers' environmental attitudes and environmental management in hotel companies. Doctoral Dissertation, Virginia Polytechnic Institute and State University, Virginia, USA.

Quinetta, M. R., Christopher J. C., \& Shaul, O. (2005). The effects of recruitment message specificity on applicant attraction to organizations. Journal of Business and Psychology, 19(3), 319-339.

Riordan, C. M., Gatewood, R. D., \& Bill, J. B. (1997). Corporate image: employee reactions and implications for managing corporate social performance. Journal of Business Ethics, 16(4), 401-412.

Rynes, S. L., \& Cable, C. M. (2003). Recruitment research in the twenty-first century. In W. C. Bor Man, D. R. Ilgen, \& R. J. Klimoski (Eds.), Handbook of psychology: Industrial and organizational psychology (pp. 55-76). Hoboken, NJ: John Wiley and Sons.

Rynes, S. L., Bretz, R. D., \& Gerhart, B. (1991). The importance of recruitment in job choice: A different way of looking. Personnel Psychology, 44(3), 487-521.

Schneider, B. (1987). The people make the place. Personnel Psychology, 40(3), 437-454.

Sims, R. L., \& Kroeck, K. G. (1994). The influence of ethical fit on employee satisfaction, commitment, and turnover. Journal of Business Ethics, 13(12), 939-947.

Smith, D.B. (2008). The People Make the Place: Dynamic Linkages between Individuals and Organizations. New York, NY: Taylor and Francis.

Soelber, P.O. (1967). Unprogrammed decision making. Industrial Management Review, 8(2), 19-29.

Spence, M. (1973). Job market signaling. Quarterly Journal of Economics, 87, 355-374. 
Surroca, J, Tribo, J., \& Waddock, S. (2010). Corporate responsibility and financial performance: The role of intangible resources. Strategic Management Journal, 31, 463490.

Tom, V. R. (1971). The role of personality and organizational images in the recruiting process. Organizational Behavior and Human Performance, 6(5), 573-592.

Turban, D. B., Campion, J. E., E Eyring, A. R. (1995). Factors related to job acceptance decisions of college recruits. Journal of Vocational Behavior, 47, 193-213.

Turban, D. B., \& Greening, D. W. (1997). Corporate social performance and organizational attractiveness to prospective employees. Academy of Management Journal, 40(3), 658-672.

Uggerslev, K. L., Fassina, N. E., \& Kraichy, D. (2012). Recruiting through the stages: A meta-analytic test of predictors of applicant attraction at different stages of the recruiting process. Personnel Psychology, 65, 597-660.

Valentine, S., Godkin, L., \& Lucero, M. (2002). Ethical context, organizational commitment, and person-organization fit. Journal of Business Ethics, 41(4), 349-360.

Wanous, J. (1992). Organizational Entry: Recruitment, Selection, and Socialization of Newcomers (2nd ed.). Upper Saddle River, NJ: Pearson Prentice Hall.

Zairi, M., \& Peters, J. (2002). The impact of social responsibility on business performance. Managerial Auditing Journal, 17(4), 174-178. 